\title{
PROBLEMATIKA EKSISTENSIAL PENDIDIKAN HUMANIORA BERBASIS MEDIA TEKNOLOGI DIGITAL SECARA DARING
}

\author{
Kasdin Sihotang \\ Unika Atma Jaya Jakarta \\ email: kasdinatma66@gmail.com
}

\begin{abstract}
Education is a path of humanization and hominization. Through education the subject develops multidimension of human being in order to be more human. The development of multidimensional humanity is existentially taking place through personal encounters between educators and students. But Covid 19 has changed all that. The essence of education based on personal and direct relationships between educators and students is considered threating, because it can become a new cluster in the spread of Covid 19. Therefore, the forms of teaching that is considered appropriate is online- based learning. This learning model does not prioritize direct relationships, but rather relationships mediated by technology. This forms of relationships ceraintly has two sides. On the one hand, the use of digital technology helps reduce the anciety of parenst, while helping the government overcome the spread of virues. But on the other hand, it is also necessary to look at he fundamental problems that are present behind the use of digital technology. The fundamental problem concerns several things: first, the elimination of educational values as a form of co-living characterized by interpersonal relationships. Second, the problem of justice, be it comutative justice and legal justice that supposes the availability of technology equally and adequately as a means of use, but in reality is not. The third, the formation of digitally characterized human being, that are heterenomy, passive attitudes, and absolute dependence.
\end{abstract}

Keywords: Education, existential problems, interpersonal relationship, justice, digital technology.

\begin{abstract}
ABSTRAK
Pendidikan merupakan jalan humanisasi dan hominisasi. Melalui pendidikan subjek mengembangkan dimensi-dimensi diri manusia supaya lebih manusiawi. Pengembangan humanitas multidimensi itu secara eksistensial berlangsung melalui perjumpaan personal antara pendidik dan peserta didik. Namun Covid-19 telah mengubah semua itu. Esensi pendidikan berbasis relasi personal dan langsung antara pendidik dan peserta didik justru dianggap mengancam, karena dapat menjadi klaster baru dalam penyebaran virus. Karena itu pula bentuk pengajaran yang dianggap sesuai adalah pembelajaran berbasis daring. Model pembelajaran ini tidak mengedepankan relasi langsung, melainkan relasi yang dimediasi oleh teknologi. Bentuk relasi demikian tentunya mempunyai dua sisi. Di satu sisi tentu penggunaan teknologi digital membantu mengurangi kecemasan para orang tua sekaligus membantu pemerintah mengatasi penyebaran Covid-19. Namun di lain sisi, di balik itu perlu pula dicermati problem mendasar yang hadir di balik penggunaan teknologi digital. Problem mendasar itu menyangkut beberapa hal. Pertama, eliminasi nilai-nilai pendidikan sebagai bentuk hidup bersama yang ditandai dengan relasi interpersonal. Kedua, problem keadilan, baik itu keadilan komutatif dan keadilan legal yang mengandaikan adanya ketersediaan teknologi secara sama dan memadai sebagai sarana yang digunakan, namun dalam kenyataannya tidak. Ketiga, terbentuknya karakter manusia digital yang ditandai dengan sikap heteronom dan pasif serta ketergantungan multlak.
\end{abstract}

Kata Kunci: Pendidikan humaniora, persoalan eksistensial, relasi interpersonal, keadilan, teknologi digital. 


\section{PENDAHULUAN}

Satu hal yang tidak bisa dihindari sebagai dampak dari Wabah Covid-19 adalah perubahan. Dan perubahan itu menyentuh segala bidang. Dunia pendidikan juga tidak terlepas dari tuntutan perubahan itu. Dalam dunia pendidikan, perubahan yang paling menonjol terkait dengan bentuk relasi yang dibangun antara pendidik dan peserta didik. Covid 19 telah mengubah bentuk relasi itu secara fundamental. Jika sebelum wabah Covid 19 relasi peserta didik dengan pendidik terjadi secara langsung, di masa pandemik ini, bentuk relasi demikian berubah menjadi tidak langsung atau termediasi.

Dalam pelaksanaan pendidikan, teknologi digital pun menjadi sesuatu yang tidak bisa dihindari, bahkan menjadi sarana satu-satunya dalam menjalankan proses pembelajaran. Jika sebelum wabah Covid-19, penggunaan teknologi digital sebagai media pembelajaran masih bersifat terbatas, bahkan menjadi sebuah prestise bagi Lembaga pendidikan, di era pandemik pemanfaatan sarana teknologi demikian menjadi sebuah keharusan. Dengan kata lain, teknologi digital menjadi conditio sine qua non, atau menjadi syarat mutlak demi berlangsungnya proses pembelajaran. Sebelum wabah, perjumpaan langsung antara pendidik dan peserta dididik, diyakini oleh para pelaku pendidikan sebagai hal yang memungkinkan proses pendidikan berlangsung secara baik, namun selama wabah, asumsi demikian justru dianggap sebagai sesuatu yang kurang tepat. Maka yang relevan dibangun justru relasi berbentuk mediasi, yakni perjumpaan dan pembelajaran yang termediasi melalui penggunaan perangkat teknologi digital.

Tidak bisa dimungkiri memang bahwa teknologi memiliki sejumlah manfaat yang membuat hidup manusia menjadi semakin efektif dan efisien. Erich Smith dan Jaren Cohen menyebutkan tujuh hal positif yang dibawahakan oleh teknologi, yakni (1) meringankan beberapa penyebab yang sulit diatasi, seperti minimnya kesempatan belajar dan peluang ekonomi; (2) semakin mengefisienkan dunia nyata, karena jangkauan konektivitas dunia digital yang semakin luas, (3) terjadinya perubahan yang meluas dalam mengaskses dan menggunakan informasi yang tingkatnya terus bertambah dari waktu ke waktu, (4) tumbuh dan berkembangnya kemampuan menghimpun dan mendayagunakan data yang dijadikan sebagai alat ukur keberhasilan program dengan lebih baik, (5) mengefisienkan banyak tugas harian yang remeh bagi warga, (6) mempermudah komunikasi peristiwa-peristiwa penting dalam kehidupan seseorang, serta (7) mendorong inovasi dan kesempatan yang lebih dalam berusaha ${ }^{1}$.

Disadari atau tidak, dalam pendidikan, ketujuh manfaat di atas juga hadir, atau minimal mempengaruhi bentuk dan pola pembelajaran. Ini berarti, di satu sisi perangkat teknologi digital memudahkan manusia dalam mengatasi berbagai problem dan memenuhi kebutuhan-kebutuhan mulai dari perencanaan, proses, sampai evaluasi dapat dilaksanakan secara leluasa dan lancar dengan menggunakan perangkat teknologi digital. Dengan perangkat teknologi digital demikian juga pendidik dan peserta didik secara mudah mengakses sumber-sumber materi perkuliahan dan pembelajaran. Hal lain, bahwa ruang dan waktu tidak lagi menjadi penghalang dalam pelaksanaan pembelajararn. Apa yang dipikirkan oleh J Schumpeter dengan teminologi aspasial dan atemporal, sekarang sungguh-sungguh menjadi sebuah kenyataan. Artinya, pembelajaran tidak harus dilakukan pada tempat tertentu, melainkan bisa dilaksanakan di mana saja dan dalam waktu fleksibel.

${ }^{1}$ Bdk. Erich Schmidt dan Jaren Cohen. 2014. Era Baru Digital: Cakrawalu Baru Negara, Bisnis dan Hidup Kita. Jakarta: Kompas Gramedia, hal. 1-6. 
Namun di sisi lain, perlu diingat bahwa di balik berbagai utilitas teknologi digital, terselip masalah eksistensial yang justru menjadi antithesis terhadap esensi dan tujuan pendidikan, serta membawa dampak mendasar bagi pembentukan kepribadian anak. Untuk itulah, kita perlu mengidentifikasi persoalan eksistensial yang ada di balik pemanfaatan teknologi digital demikian dan mencoba memberikan pemikiran solutif berhadapan dengan persoalan eksistensial yang kemungkinan muncul. Inilah yang akan menjadi fokus pembahasan dalam paper ini.

\section{DISKUSI DAN HASIL}

Pembahasan paper ini meliputi lima poin penting, yakni a) hakikat pendidikan secara umum, b) pendidikan humaniora secara khusus, dan c) Hakikat teknologi digital, d) identifikasi persoalan eksistensial yang muncul di balik pemanfaatan teknologi digital, serta e) gagagasan alternatif berhadapan dengan persoalan eksistensial.

\section{a. Hakikat Pendidikan sebagai Humanisasi dan Hominisasi}

Apakah pendidikan itu? Pertanyaan ini bukanlah sesuatu yang baru. Namunpun demikian, pertanyaan ini tetap relevan diajukan untuk mengingatkan kita lagi tentang esensi pendidikan yang sesungguhnya. Dengan menghadirkan kembali hakikat pendidikan ini, kita bisa mengidentifikasi apakah pemanfaatan teknologi, apalagi pemutlakan penggunaan sarana teknologi digital sungguh-sungguh mewujudkan hakikat pendidikan sesungguhnya atau tidak. Atau malah di baliknya ada persoalan mendasar yang memerlukan pencermatan dan gagasan antisipatif.

Dalam menjawab pertanyaan di awal paragraph di atas, kita bisa merujuk gagasan $\mathrm{N}$ Driyarkara. $\mathrm{N}$ Driyarkara ${ }^{2}$ menyatakan bahwa pendidikan merupakan perbuatan yang fundamental, yakni perbuatan yang mengubah dan menentukan hidup manusia. Hal ini terejawantah dalam dua belah pihak, yakni pendidik dan peserta didik. Pagi pendidik, dengan mendidik, ia bertindak dalam menentukan sikap. Demikian halnya bagi peserta didik, dengan menerima pendidikan, dia bertumbuh menjadi manusia.

Tujuan utama dari pendidikan menurut Driyarkara adalah humanisasi dan hominisasi. Artinya apa? Dikatakan humanisasi, karena kegiatan mendidik merupakan sebuah pertolongan pemanusiaan manusia muda. Dan pertolongan pemanusiaan itu merupakan perbuatan yang diberikan oleh orang yang bertanggung jawab kepada generasi muda untuk membantu pembentukan dirinya. Karena itu pula pendidikan merupakan upaya pemanusiaan. Pemanusiaan ini adalah baik dari pihak pendidik maupun dari pihak anak. Anak didik memanusia, demikian juga pendidik memanusia. Keduanya melakukan pemanusiaan dalam aktivitas pendidikan.

Dikatakan hominisasi, karena dalam pendidikan terjadi juga pengelolaan terhadap aspek-aspek biologisnya secara menyeluruh, termasuk pengelolaan naluri-naluri yang melekat dalam diri peserta didik dan pendidik. Driyarkara menyebutnya "penjadian manusia" 3 . Di sini peserta didik dan pendidik sama-sama mengakui bahwa keduanya terus mengalami proses pembentukan

\footnotetext{
${ }^{2}$ Lihat A Sudiarja, SJ, cs (ed). 2006. Karya Lengkap Driyarkara: Esai-Esai FIlsafat Pemikiran yang Terlibat Penuh dalam Perjuangan Bangsanya. Jakarta dan Yogyakarta: Gramedia dan Kanisius, hal. 413.

3 Ibid., hal 368.
} 
secara fisik bersama dengan pembentukan kepribadiannya. Dengan demikian pendidikan adalah hidup bersama dalam kesatuan relasi di mana terjadi tindakan saling memanusiakan ${ }^{4}$.

Selain pemanusiaan, Driyarkara menambahkan bahwa pendidikan berhubungan dengan pembudayaan. Artinya, melalui pendidikan, anak masuk ke dalam alam budaya, dan alam budaya tidak terlepas dari diri anak. Namun pemasukan di sini juga menunjuk aktivitas pendidik secara aktif dan pasif. Anak dimasukkan tetapi juga memasukkan dirinya. Demikian juga kebudayaan tidak akan masuk ke dalam diri anak kalau anak tidak memasukkannya sendiri. Dengan kebudayaan di sini yang dimaksudkan juga adalah hominisasi sebagai tingkat fundamental yang niscaya.

Driyarkara lebih lanjut menyatakan bahwa pembudayaan merupakan proses ke arah pembudayaan yang berdikari oleh anak sendiri sebagai manusia purnawan. Namun, membudayakan tidak bersifat individual belaka, melainkan bersifat sosial, karena juga membudayakan orang lain. Dalam konteks itulah hal yang tidak bisa diabaikan adalah nilai-nilai. Karena itu hakikat pendidikan melalui humanisasi dan hominisasi, nilai-nilai selalu hadir. Dengan kata lain, pendidikan merupakan kegiatan mempelajari hidup, yang sekaligus juga mempelajari pelaksanaan nilai-nilai. Pelaksanaan nilai-nilai itu merupakan perjumpaan langsung antara aktivitas pendidik dan aktivitas anak didik. Dalam rangka pemanusiaan dan pembudayaan itu, Driyarkara mengingatkan tiga esensi mendasar sebagai pribadi, yakni cipta, karsa, dan rasa. Tiga hal inilah yang membentuk anak didik menjadi manusia purna ${ }^{5}$.

Dari paparan di atas jelaslah, pendidikan merupakan upaya pemanusiaan dan pembudayaan. Pemanusiaan karena melalui dan di dalam pendidikan, baik pendidik maupun anak didik menghadirkan dimensi mendasar kemanusiaannya, yakni sebagai pribadi yang bebas, otonom, dan mampu menentukan keputusan mana yang terbaik dalam hidupnya, serta memberi ruang bagi dimensi personal untuk tumbuh berkembang secara utuh. Sebagai pembudayaan, pendidikan menjadi ruang di mana pendidik dan anak didik melatih diri untuk bertanggung jawab, dan berkreasi, tepatnya berdinamika dengan memberi ruang bagi cipta, rasa dan karsa.

\section{b. Hakikat Pendidikan Humaniora}

Sesudah kita jelaskan hakikat dari pendidikan, selanjutnya kita membahas esensi dari pendidikan humaniora. Kata "humaniora"6 merupakan istilah serapan dari bahasa Latin. Arti harafiah humaniora (bentuk jamak) adalah "hal-hal yang lebih manusiawi." Istilah tersebut dibentuk dari kata humanus (adjektiva, tunggal), artinya "manusiawi". Humanior merupakan bentuk komparatifnya, yang artinya "lebih manusiawi". Sementara kata humanus merupakan bentukan dari kata dasar, yakni homo (tunggal) atau homines (jamak) yang berarti "manusia". Mengacu pada etimologi istilah tersebut, maka makna humaniora adalah studi atau kelompok ilmu-ilmu yang bertujuan untuk membentuk peserta didik menjadi lebih manusiawi (humanisasi).

Kata humaniora dalam konteks pendidikan digunakan secara umum di zaman Renaisans. ${ }^{7}$ Zaman ini merupakan masa peralihan dari Abad Pertengahan ke Zaman Modern di Eropa. Renaisans

\footnotetext{
${ }^{4}$ Ibid., hal., 416.

${ }^{5}$ Ibid., hal. 231-236.

${ }^{6}$ Lihat Bartolomeus Samho. 2008. "Humanisme Yunani Klasik dan Abad Pertengahan” dalam Bambang Sugiharto (ed). Humanisme dan Humaniora: Relevansinya bagi Pendidikan. Yogyakarta: Jalasutra, hal.1. 7 Ibid., hal. 2.
} 
berasal dari kata Latin, renascere, berarti "kelahiran kembali". Yang lahir kembali adalah kebudayaan Yunani dan Romawi klasik. Kedua zaman ini ditandai dengan bangkitnya bidang sastra, kesenian, seni rupa, dan arsitektur. Bahkan berbagai bidang ini menjadi penanda kejayaan kebudayaan pada masa tersebut.

Kelahiran kembali dua kebudayaan tersebut berimplikasi pada kelahiran paham humanisme sebagai gerakan intelektual ${ }^{8}$. Humanisme juga merupakan penanda Renaisans. Dalam kaitannya dengan humaniora, humanisme sebagai sebuah gerakan intelektual yang bertujuan memajukan humanitas (kemanusiaan) manusia, berpijak pada dan menimba inspirasi dari sastra serta kebudayaan Yunani dan Romawi klasik. ${ }^{9}$

Jika ditilik historisitas pendidikan humaniora, kita menemukan dinamika dalam pengembangannya. Di Zaman Yunani, pendidikan ini dikembangkan oleh dua kutup, yakni kaum sofis dan kutup kaum filosof ${ }^{10}$. Kutup pertama, yakni kaum sofis memberi fokus pada kemampuan beretorika dengan tekanan gugahan dan dorongan pada emosi dan sensitivitas peserta didik. Sedangkan kaum filosofis membangun dan menggerakkan penalaran dialektis agar peserta didik mampu membangun penalaran dialektis dan argumentasi yang benar. ${ }^{11}$ Sementara di Abad Pertengahan, Logika, grammar, dan retorika (Trivium), dan aritmetika, musik, geometri dan astronomi (quadrivium) tumbuh dan berkembang. Ini dinamakan dengan artes liberales/liberal arts ${ }^{12}$.

Dengan logika, kemampuan peserta didik berpikir lurus dan jernih diasah. Dengan tata bahasa, akal mereka diasah agar mampu menciptakan dan mengombinasikan simbol-simbol sehingga membentuk kata dan kalimat yang bermakna. Melalui retorika, diharapkan seni mengkomunikasikan pikiran peserta didik melalui tata bahasa yang teratur terbentuk. Sementara aritmatika dijadikan sebagai seni mendidik orang muda agar mampu memikirkan konsep bilangan. Aplikasi konsep bilangan terwujud melalui kombinasi not-not angka pada musik sehingga menghasilkan bunyi yang harmonis. Konsep bilangan juga diaplikasikan dalam penjumlahan, perkalian, pengurangan. Darinya, jelaslah bahwa pembelajaran matematika merupakan seni mengaplikasikan konsep bilangan secara konkret. Geometri adalah seni membentuk konsep spasial (space). Ilmu astronomi merupakan aplikasi konsep spasial. Jadi, pembelajaran geometri dan astronomi merupakan seni mengaplikasikan konsep spasial.

Jika kita mencermati kedua jaman tersebut, kita menemukan bahwa pendidikan humaniora berfokus pada pembentukan manusia secara utuh, yakni menjadi pribadi yang berkarakter. Dengan kata lain, pendidikan humaniora merupakan upaya untuk menjadi pribadi yang bermuutu secara utuh. Karena itu esensi pendidikan tidak diletakkan pada tujuan, atau pemanfaatan sarana, tetapi pada proses holistic dan utuh.

Dalam perkembangan selanjutnya, sebagai akibat dari kemajuan ilmu pengetahuan alam dan sosial, tekanan pendidikan humaniora bergeser, tidak lagi pada pembentukan kepribadian, tetapi juga pada metode ilmiah yang tujuannya menghasilkan pengetahuan ilmiah. Karakter saintifik ini

8 Ibid., hal. 46.

${ }_{9}^{9}$ Ibid., hal. 5.

${ }^{10}$ Nigel Tubbs. 2014. Philosophy and Modern Liberal Arts Education. New York: Palgrave Macmillan, hal. 7.

${ }^{11}$ Ibid., hal. 7

12 Lihat M. Sastrapratedja, SJ. 2013. Pendidikan sebagai Humanisasi. Jakarta-Yogyakarta: Pusat Kajian Filsafat dan Pancasila-SDU Press, hal. 187. 
lebih mendapat perhatian, dibandingkan dengan karakter kepribadian peserta didik. Karena itu pada periode ini terminologi yang digunakan bukan lagi pendidikan humaniora, tetapi ilmu-ilmu humanitis. Kunci di sini adalah penggunaan metode kerja ilmu pengetahuan ilmiah dan hermeneutika sosial.13 Dengan ini, pendidikan bahasa, logika, pendidikan kewarganegaraan, pendidikan agama, etika tidak saja difokuskan pada tujuannya untuk mengasah peserta didik agar berkepribadian humanistis dan religius, melainkan juga mendukung terbentuknya berkarakter sainfik. Peserta didik yang berkarakter saintifik akan menggunakan pendekatan saintifik (ilmiah) dalam mengelola aneka persoalan hidup sehari-hari di tengah masyarakat. Jadi, ilmu pengetahuan ditempatkan sebagai sebuah kebijaksanaan ${ }^{14}$.

\section{c. Esensi Teknologi Digital}

Setelah kita membicarakan hakikat pendidikan dan pendidikan humaniora, sekarang kita membicarakan esensi teknologi. Perhatian pada teknologi dari kacamata filosofis -baik secara tidak langsung atau secara khusus langsung membahasnya- sudah diberikan oleh sejumlah filsuf. Filsuf pertama yang menggunakan terminologi "tekne" adalah Sokrates. Istilah yang terkenal dari filsuf ini adalah "maieutike techne". 15 Sokrates menggunakan istilah "techne" dalam konteks proses penyampaian pengetahuan, yakni seperti seorang bidan (maieutike). Kata "techne" merupakan sebuah cara, tepatnya metode pengajaran. Menurut Sokrates, sebagaimana seorang bidan hanya bertugas membantu, mendorong dan memotivasi sang ibu yang hamil untuk bergerak aktif dan berusaha untuk mengeluarkan bayi dari rahimnya, demikian halnya seorang guru/pendidik bertugas untuk membantu, mendorong dan memotivasi anak didik untuk aktif mencari dan mengupayakan pengetahuan.

Filsuf lain yang cukup intens membahas teknologi adalah Martin Heidegger (1889-1976). Filsuf Jerman ini melihat teknologi bukan sekedar persoalan teknis, tetapi juga menyentuh sesuatu yang mendasar tentang eksistensi manusia. Karena itu Heidegger mencoba mengelaborasinya sebagai persoalan filsafat. Menjadi persoalan filsafat, karena dengan teknologi, manusia melengkapi bentuk relasinya, sekaligus mengungkap kebenaran di dalamnya.

Dalam Being and Time ${ }^{16}$ Heidegger membedakan kualitas hidup manusia dalam berelasi dengan sesamanya (Zuhandenes) dan benda-benda (Forhandenes). Hubungan manusia dengan bendabenda hanya bersifat fungsional dan aksidental. Dikatakan bersifat fungsional, karena hanya terkait dengan kebutuhan dan keperluan. Misalnya, seorang pedagang daging berhubungan dengan pisau hanya pada saat ia membutuhkan alat tersebut untuk memotong daging. Dikatakan

13 Lihat Ignas Kleden. 2017. "Paradigma Ilmu Pengetahuan: Tantangan Penelitian Ilmu-ilmu Sosial dan Humaniora di Indonesia” dalam Ignas Kleden dan Taufik Abdullah (Ed.), Paradigma Ilmu Pengetahuan dan Penelitian Ilmu-ilmu Sosial dan Humaniora di Indonesia. Jakarta: LIPI Press, hal. 1-132.

${ }^{14}$ Lihat Mikhael Dua. 2019. "Ilmu Pengetahuan sebagai Strategi Budaya” dalam Dr A Setyowibowo, SJ (ed), Manusia dan Budaya Indonesia, Jakarta: Penerbit Kompas, hal. 149-150.

15 Maieutike techne berarti teknik kebidanan. Sokrates mengadopsi teknik itu sebagai metode pengajarannya di agora-agora (pasar-pasar). Dengan metode itu, guru Platon itu mengeluarkan isi pikiran dari dalam pikiran orang-orang yang mendengarnya. Bagi Socrates, setiap orang yang mendengar pengajarannya, sudah memiliki isi pikiran mengenai hal tertentu. Oleh karena itu, isi pikiran setiap orang harus dikeluarkan lebih dulu, seperti bidan membantu ibu hamil untuk melahirkan anak dari dalam rahim. Setelah isi pikiran itu diketahui, selanjutnya Socrates memperbaikinya dengan pikiran-pikiran filosofis.

16 Lihat lengkap, Martin Heidegger. 1996. Being and Time. New York: State University of New York, hal. 196211. 
bersifat aksidental karena hubungan dengan benda terjadi pada waktu tertentu saja. Dalam relasi ini, manusia tidak perlu melibatkan diri secara total dan tidak pula memiliki pengaruh terhadap keberadaan pisau. Demikian sebaliknya, kehadiran pisau tidak mempengaruhi sisi kemanusiaan pemotong daging. Kebersamaan dengan benda-benda bersifat terbatas dan tertutup, tidak ada interkomunikasi.

Berbeda dengan relasi "Ada" dengan benda-benda, interaksi "Ada" dengan "Ada" (baca: manusia dengan manusia) justru terjadi dalam interkomunikasi. Dalam relasi ini persona memasuki orang-orang lain dan sebaliknya. Hubungan manusia dengan sesama manusia ditandai oleh keterbukaan dan penyerahan diri, yang disebut Heidegger sebagai autentisitas. Di dalamnya ada pengakuan kesederajatan dan keterlibatan diri terhadap orang lain secara penuh. Karena itu, hubungan dengan Vorhandenes lebih tepat dikisahkan sebagai hubungan antara subjek yang memberi dengan subjek yang menerima. Di dalamnya subjek menyadari bahwa dirinya tidak menjadi diri yang sebenarnya tanpa kehadiran orang lain. Ia sadar bahwa perkembangannya hanya terjadi karena keberadaan orang lain. Dengan demikian "Aku" menjadi diriku, karena ada "Engkau". Dan "Aku" diperteguh oleh "Engkau" dan "Aku" memperteguh "Engkau". Realitas sosialitas ini tidak bisa disangkal dan tidak pula mampu dihindari. Kebersamaan ini bagaikan sebuah keharusan yang tidak terelakkan dan seolah-olah menjadi "sebuah tragedi". Jadi, ada bersama merupakan imperatif kategoris bagi manusia.

Kendati membuat demarkasi yang jelas antara relasi Ada dengan manusia dan relasi Ada dengan teknologi, namun Martin Heidegger juga tidak menyangkal adanya aspek filosofis dalam pemanfaatan teknologi ${ }^{17}$. Menurutnya teknologi tidak sekedar sebuah alat untuk mencapai tujuan tertentu, tetapi juga merupakan upaya penyingkapan dimensi mendasar manusia. Teknologi merupakan sebuah dunia penyingkapan dan ketidaktersembunyian tentang kebenaran, yang diistilahkannya dengan aletheia. ${ }^{18}$ Terkait dengan ini Heidegger memunculkan dua istilah, yakni "yang ontis" dan "yang ontologis". Teknologis sebagai "yang ontis" ketika manusia menyikapi teknologi semata-mata sebagai sesuatu yang bernilai guna untuk mencapai tujuan tertentu. Artinya, teknologi digunakan hanya bersifat instrumentalistik dan antropologis, yakni sebagai alat untuk kepentingan manusia. Di dalamnya tidak ada pengungkapan kebenaran. Sedangkan teknologi sebagai "yang ontologis" ketika teknologi digunakan untuk mengungkap kebenaran, yang dinamakan oleh Heidegger dengan modus alētheia. Dan bagi Heidegger justru di sinilah letak dari esensi filosofis dari teknologi. Dengan kata lain, manusia membuka diri terhadap kebenaran yang menyingkapkan dirinya melalui penggunaan alat-alat teknologi. Jadi, alat-alat teknologi bermakna sejauh dalam penggunaannya memungkinkan manusia mengerti kebenaran (yang benar). Sebaliknya, bila alat-alat teknologi ditempatkan semata-mata sebagai

17 Lihat Martin Heidegger. 1978. Basic Writings - from Being and Time (1927) to The Task of Thingking (1964), (Edited, with general introduction and introductions to each selection by David Farrel Krell). London and Henley: Routledge \& Kegan Paul, hal. 287-317.

18 Teknologi sebagai sarana dan alat untuk mencapai tujuan tertentu manusia, bagi Martin Heidegger, berarti teknologi baru pada level ontis. Teknologi tidak sekedar perkara ontis. Teknologi adalah perkara ontologis, yakni Ada (Being) yang menyingkapkan dirinya. Lihat, David Farrel Krell - Ed., 1978, hal. 288-289; F. Budi Hardiman, 2016, hal. 70-71; Francis Lim, 2008, hal. 46. 
alat penaklukan dan manipulasi, maka teknologi sebagai modus kebenaran menyingkapkan dirinya tidak terpenuhi. ${ }^{19}$

Pemikir lain yang cukup intens membicarakan teknologi adalah Albert Borgmann. Ia bahkan dijuluki dengan gelar Filsuf Teknologis Artifaktis ${ }^{20}$. Borgmann menyatakan bahwa informasi teknologis sebagai artifak Teknologi Informatika (TI) yang dibawa oleh simbol angka digital adalah informasi yang berfungsi sebagai realitas tandingan dari realitas yang sesungguhnya. TI adalah mesin komputer yang merupakan kecerdasan tiruan atau intelegensi artifisial. Begitu cerdasnya TI sehingga informasi teknologis mampu menghadirkan sesosok pribadi melalui ruang siber dan menjadikan manusia tertipu atau merasa tidak pasti apakah orang tersebut pribadi yang sesungguhnya (real person) atau yang maya (virtual person).

Bagi Borgmann, dengan mengandalkan intelegensi tiruan dan realitas maya yang semakin canggih, informasi teknologis menghadirkan sosok yang tidak pasti tersebut menjadi semakin memiliki kepribadian yang menarik dan dapat diaktifkan seperti yang sesungguhnya. Ketika manusia memasuki ruang siber, ia terkadang mereduksikan dirinya sendiri menjadi pribadi yang dangkal, tidak utuh, dan termotivasi oleh kebanalan semacam itu, padahal informasi teknologis mudah meniru dan memperbanyak pribadi semacam itu dengan sendirinya. Di sini terjadi penggantian identitas pribadi di ruang maya yang disebut dengan istilah awatara ${ }^{21}$. Penggantian identitas itu terjadi secara berulang-ulang yang menyebabkan terjadinya perbanyakan tanpa perlu keberadaan yang asil (copies without originals). Borgmann melihat bahwa proses demikian jutru semakin membawa kebingungan bagi manusia karena tidak lagi mampu membedakan siapa sedang berhadapan dengan siapa.

Dalam situasi demikian manusia kehilangan karakter dan makna dirinya sendiri. Situasi ini merupakan situasi yang mengancam kemanusiaan. Dalam teknologi modern, terjadi sesuatu yang membahayakan dan yang tidak dapat dihindari, yakni paradigma peranti di mana manusia harus mengikuti paradigma ini. Namun dalam paradigma ini manusia dimiskinkan dari kemanusiaannya tanpa disadari sepenuhnya. Manusia hanya berhadapan dengan fungsi informasi sebagai realitas tandingan yang bersifat maya. Realitas maya bukan sekedar realitas tiruan yang diaktualisasikan berdasarkan infrormasi kultural. Realitas maya yang dihadirkan secara teknologis yang bukan sekedar menggantikan realitas sesunggunya, melainkan dialami sebagai yang jauh lebih unggul daripadanya, padahal realitas yang diaktualisasikan lewat informasi kultural adalah realitas yang penuh beban dan bobot, sementara realitas maya merupakan realitas yang meskipun terpisah dari dunia yang dialami dalam keseharian tetapi sangat mudah dikonsumsi.

Selanjutnya kita membicarakan kata "digital". Merujuk kamus elektronik Merriam-webster, kata didigital didefinisikan sebagai "of, relating to, or using calculation by numerical methods or by

${ }^{19}$ Lihat Judith Simon. 2009. “Distributed Epistemic Responsibility in a Hyperconnected Era” dalam Luciano Floridi (Ed), The Onlife Manifesto Being Human in a Hyperconnected Era, Springer Cham Heidelberg, New York, Dordrecht, London, hal, 150-151.

20 Pemikiran Borgmann ini lihat dalam Margawati van Eymeren dalam Informasi Teknologis: Antropologi Teknologis Berdasarkan Pemikiran Albert Borgmann dan Walter J Ong. Jakarta: Pusat kajian Filsafat dan Pancasila, 2013, hal 94.

21 Ibid., hal. 228. 
discrete units; composed of data in the form of especially binary digits. ${ }^{22}$ Selain itu, kata digital diartikan sebagai gambaran mengenai keadaan bilangan yang terdiri dari angka 0 dan 1 atau off dan on. Arti lain digital adalah sinyal atau data yang dinyatakan dalam serangkaian angka 0 dan 1, dan secara umum diwakili oleh nilai-nilai kuantitas fisik, seperti tegangan atau polarisasi magnetik. Roger Fidler mengaitkan istilah digital dengan jari-jari tangan dan kaki yang digunakan manusia untuk menghitung dan mewakili data bilangan. Teknologi ini baginya hanyalah system perhitungan yang luar biasa cepat dalam memproses dan memperlakukan segala bentuk infomasi sebagai nilai-nilai angka23.

Jadi, teknologi digital merupakan modernisasi penggunaan teknologi baru dengan sistem kerja artificial intelligence super canggih. ${ }^{24}$ Dan revolusi teknologi ini membentuk sebuah sistem kebudayaan secara berkelanjutan. Manusia dengan kapasitas akal budinya membuat perangkat komputer dan internet yang dilengkapi perangkat halus artificial intelligence (AI). Teknologi digital kemudian menarik manusia masuk ke dalamnya. Bersamaan dengan itu instrumen ini memasuki ruang publik dan ruang privat hidup manusia. Penyusupan teknologi digital ke dalam kehidupan manusia adalah bagian dari sebuah fenomena yang lebih luas dan berlangsung terus menerus, yang pada akhirnya karenanya melahirkan budaya digital, di mana segala sesuatu tampak terjadi dengan kecepatan yang direkayasa demi menghasilkan perubahan besar dan luas dalam waktu sangat singkat. ${ }^{25}$

\section{d. Problem Eksistensial Pembelajaran secara Daring}

Setelah kita membahas hakikat pendidikan dan pendidikan humaniora, serta esensi dari teknologi digital, sekarang kita mengidentifikasi persoalan eksistensial yang ada di balik pemanfaatan media teknologi digital. Idenfikiasi persoalan eksistensial lebih terfokus pada halhal yang terkait dengan esensi pendidikan itu sendiri. Yang dimaksudkan dengan problem eksistensial adalah persoalan-persoalan mendasar yang muncul dalam pemanfaatan teknologi digital dari sudut pandang esensi pendidikan dan pendidikan humaniora itu sendiri.

Sekurang-kurangnya, ada tiga persoalan mendasar dalam pemanfaatan teknologi digital sebagai media utama dalam proses pembelajaran, yakni relasi interpersonal yang digantikan dengan relasi mekanistik (virtual person), munculnya ketidakadilan, dan terbentuknya pribadi yan berkarakter digital. Kita akan membahas satu per satu persoalan eksistensial tersebut.

\section{a) Relasi Impersonal Mekanistik}

Sebagaimana sudah dibahas di atas bahwa hakikat pendidikan adalah humanisasi dan hominisasi. Dikatakan humanisasi karena melalui pendidikan, pendidik dan anak didik mengalami pemanusiaan. Dimen-dimensi mendasar kemanusiaannya dibentuk. Demikian halnya perkembangan aspek biologisnya mendapat perhatian secara utuh. Humanisasi dan hominisasi terjadi dalam kebersamaan yang ditandai dengan hubungan interpersonal, baik itu antara webster.com/dictionary/digital\#: :text=1\%20\%3A\%20relating\%20to\%20or\%20using,digits $\% 20$ di gital\%20images\%20digital\%20broadcasting. Diakses pada Selasa, 24 Februari 2021, pkl. 11.37. WIB.

${ }^{23}$ Lihat Roger Fidler. 1997. Mediamorphosis: Undertanding New Media, Thousan Oaks, California \& New Delhi: Pine Forge Press, hal. 72.

24 Ibid., hal. 72.

25 Ibid., hal. 72. 
pendidik dengan peserta dididik, maupun antara peserta didik dengan peserta didik. Dalam relasi langsung yang bersifat personal itu jati dirinya terbentuk secara dinamis. Dengan kata lain, pembentukan kepribadian secara utuh justru menyentuh tidak saja dimensi kognitif anak didik, tetapi juga dimensi afektif dan psikomotorik baik pendidik maupun peserta didik secara langsung.

Dengan penggunaan media teknologi digital secara daring, relasi humanistik dan interpersonal di atas justru tidak terjadi. Perjumpaan yang termediasi bukanlah perjumpaan yang sesungguhnya. Perjumpaan itu merupakan perjumpaan yang dimediasi oleh instrumen. Karena itu pula perjumpaan demikian sifatnya mekanistik, dan bukan bersifat personal. Sentuhan perjumpaan langsung sangatlah berbeda dengan sentuhan perjumpaan tidak langsung atau dimediasi. Dalam perjumpaan termediasi, meminjam terminology Martin Heidegger, tidak terjadi autentisitas, yakni penghadiran diri peserta didik yang sebenarnya dan total. Yang terjadi adalah penghadiran diri yang artifisial dan parsial.

Hal yang sama juga ditekankan oleh Borgmann ${ }^{26}$. Menurut Borgmaan, relasi manusia berbasis teknologi digital telah menempatkan peserta didik bukan lagi sebagai sebuah kenyataan hidup yang sesungguhnya, tetapi sebuah realitas yang palsu. Mengapa disebut demikian? Karena relasi bebasis media teknologi demikian tidak memberi ruang bagi keunikan masing-masing pribadi untuk tampil secara otentik. Pertemuan antara pendidik dengan peserta didik memang terjadi, tetapi pertemuan itu bukan pertemuan yang otentik. Pertemuan itu merupakan pertemuan rekayasa yang keberlangsungannya sangat tergantung pada kualitas teknologi itu sendiri.

Ketika teknologi yang digunakan tidak berkualitas, maka relasi antara pendidik dengan peserta didik berhenti atau terputus sehingga relasinya pun terjadi secara tidak berkuaitas. Dengan kata lain, dalam perjumpaan bermedia teknologi digital, sisi kemanusiaan peserta didik dan pendidik yang sesungguhnya tidak hadir. Yang menentukan dalam pertemuan ini bukan lagi subjek, melainkan peranti. Dengan kata lain, tempat berlangsungnya semua kegiatan manusia dalam mengeriya yang terhubung dengan pembawa tanda digantikan dengan dunia yang berparadigma peranti. Konsekuensinya, relasi manusia di sini tidak dialami lagi sebagai sesuatu yang bermakna, melainkan bersifat artifisial belaka. ${ }^{27}$

Dari paparan di atas jelaslah bahwa pemanfaatan teknologi digital sebagai media pembelajaran secara daring menghasilkan hubungan impersonal, sekaligus mekanistik antara guru dengan peserta didik.

\section{b) Ketidakdilan}

Persoalan mendasar kedua pemanfaatan media teknologi digital secara daring dalam pendidikan adalah keadilan. Yang dimaksud di sini adalah keadilan legal dan keadilan komutatif. Tidak bisa dimungkiri bahwa keberhasilan pendidikan berbasis media teknologi secara daring tergantung pada ketersediaan sarana dan prasarana dan kualitasnya, yang diandaikan sama pada semua subjek yang terlibat. Dan sarana dan prasarana yang dimaksudkan adalah laptop, handphone, internet, dan pulsa. Ketika semua persyaratan ini dihubungkan dengan situasi peserta didik dan pendidik, maka justru di sini terjadi persoalan.

26 Lihat Borgmann dalam Megawati van Eymeren, op.cit., hal. 87.

27 Ibid., hal. 88. 
Situasi peserta didik dan pendidik sangat beragam, termasuk situasi ekonominya dan letak geografisnya. Situasi ini tentu juga mempengaruhi penyediaan sarana pendidikan. Anak-anak yang berokonomi cukup, penyediaan sarana teknologi mungkin tidak mengalami masalah. Tetapi bagi peserta didik yang berekonomi kelas menengah ke bawah, penyediaan sarana yang memadai akan menjadi persoalan besar dan utama. Demikian halnya letak geografis turut menentukan dalam hal ini. Anak-anak yang tinggal di daerah, jangankan memiliki sarana teknologi yang mumpuni seperti anak kota, mungkin memegang sarana dan prasarana demikian masih jarang.

Dalam situasi sosial ekonomi yang berbeda di atas dan kondisi daerah yang tidak memiliki perangkat teknologi yang memadai seperti jaringan, pendidikan tidak bisa berlangsung secara adil. Kondisi ini tentu membuat adanya kesempatan yang tidak sama bagi peserta didik untuk mendapatkan pendidikan. Secara lain dapat dikatakan, pendidikan justru berjalan dalam ketidakadilan. Yang bisa mengikuti proses pembelajaran secara memada hanyalah mereka yang memiliki sarana teknologi yang memadai. Sedangkan yang tidak akan sulit merasakan hal yang sama. Jadi, persoalan ketersediaan sarana prasarana bukan saja persoalan teknis, melainkan persoalan fundamental dalam proses pembelajaran.

\section{c) Karakter Manusia Digital}

Dalam pemanfaatan teknolog digital, yang mengendalikan adalah artificial intelligent. Ini dikaitkan dengan internet of things, cloud of things, dan big data. ${ }^{28}$ Istilah internet of things terkait dengan kemampuan internet menghubungkan berbagai perangkat fisik dan non-fisik dalam satu jaringan sedemikian rupa yang memudahkan pengoperasian, pengkoordinasian, pengawasan, serta meningkatakan efisiensi dan efektivitas pencapaian. Cloud of things berkaitan dengan sistem penyimpanan dan proses atau distribusi data, aplikasi, layanan untuk semua pengguna internet sehingga tidak perlu lagi menggunakan alat penyimpan seperti hardisk, flashdisk atau server pribadi. Sedangkan big data merujuk pada pertumbuhan jumlah dan rentang informasi yang bergerak secara eksponensial dengan kecepatan pertambahan yang tidak lazim, sehingga membutuhkan cara penanganan baru.

Cara kerja artificial intelligence yang berkelanjutan dalam perangkat teknologi digital membentuk budaya digital. Ini berarti aneka kegiatan manusia dalam berbagai bidang kehidupan - termasuk pendidikan- akhirnya menjadi aktivitas digital. Implikasi terdalam dari pribadi berkultur digital adalah keterciptaan manusia digital. Manusia digital merujuk pada cara berpikir, cara merasa, cara bertindak secara digital. Di sini manusia digital - meminjam istilah Herbert Marcuse - adalah manusia satu dimensi. ${ }^{29}$

Apa ciri-ciri dari manusia digital? Manusia digital satu dimensi selalu memiliki kecenderungan memperoleh suguhan pasar kapitalisme digital. Chris Skinner menegaskan bahwa manusia digital sulit membedakan mana yang bernilai dan mana yang tidak bernilai dari apa yang dilakukannya. Di situ ia justru kehilangan daya kritis, karena ketergantungan mutlak instrument yang digunakannya. Manusia digital hanya melihat benda dari sisi fungsinya, dan penilaian ini justru menjadi ukuran. Di sini manusia digital bernilai saat kita telah menjadi manusia super berkat teknologi perpanjangan hidup dan rekayasa tubuh, saat kita bergerak melampaui bumi

${ }^{28}$ Lihat Agus Sudibbyo, 2019. Jagad Digital-Pembebasan dan Penguasaan. Jakarta: KPG, hal. 212-225.

${ }^{29}$ Lihat Valentinus Saeng, CP. 2012. Herbert Marcuse-Perang Semesta Melawan Kapitalisme Global. Jakarta: Gramedia, hal. 241-264 
menuju planet lain, dan saat kita mencapai tahap di mana setiap kebutuhan fisik dan mental kita dapat dipenuhi oleh sebuah robot. ${ }^{30}$

\section{d. Gagasan Solutif: Konsientisasi Pemanfaatan Teknologi Digital}

Bahwa para pihak pada era budaya digital sekarang dan akan datang, tidak dapat mengelakkan diri dari tanggungjawab menyelenggarakan pendidikan humaniora melalui media digital tidak bisa dimungkiri. Akan tetapi di balik pemanfaatan demikian tersingkap persoalan mendasar terkait humanisasi dan hominisasi. Pertanyaan kita: Pemikiran solutif apa yang bisa ditawarkan dalam berhadapan dengan persoalan mendasar tersebut? Menjawab pertanyaan ini, menurut hemat penulis, hal yang penting secara eksistensial ada dua, pertama, kebangkitan kesadaran terhadap keterbatasan teknologi digital ketika dijadikan sebagai media pembelajaran daring, kedua; kesadaran bahwa kedudukan teknologi sebagai instrumental, tepatnya mediasi.

Seperti ditegaskan oleh Heidegger, teknologi memiliki ontologis, dan ontologinya terletak pada potensialitasnya untuk memungkinkan "sesuatu menampakkan dirinya, keluar dari persembunyiannya." 31 Namun teknologi sendiri pada dirinya sendiri tidak bisa menghadirkan dirinya, karena teknologi tidak bersifat intenstional. Yang bisa mengarahkan dirinya ke teknologi hanyalah manusia. Dengan kata lain, teknologi digital tidak mampu membawa dirinya ke hadapan manusia. Itu hanya bisa dilakukan oleh manusia itu sendiri. Secara konkret dapat dikatakan, teknologi tidak bisa menyatakan keterbatasannya kepada manusia. Manusia justru harus mencarinya dan mengangkatnya keluar dari ketersembunyiannya. Jadi, dalam memanfaatkan media teknologi digital, manusia perlu bersifat aktif untuk menyingkapkan keterbataan teknologi digital itu sendiri.

Selain terus menerus mengungkap keterbatasan teknologi, kesadaran untuk menempatkan teknologi hanya sebagai sarana dan memanfaatkannya secara efektif dan maksimal untuk hal-hal mendasar kemanusiaan juga perlu. Teknologi tetaplah sebuah sarana untuk mencapai tujuan, bukan tujuan itu sendiri. Karena itu pula nilai-nilai kepribadian peserta didik tidak boleh direduksi pada perangkat teknologi. Secara lain dapat dikatakan teknologi digital hanyalah sebuah mediasi, bukan subjek dalam pendidikan. Karena itu pula yang perlu diperhatikan secara maksimal adalah eksistensi dari subjek pendidik dan peserta didik itu sendiri. Kesadaran akan hal inilah yang bisa mengeleminir persoalan eksistensial pendidikan berbasis media teknologi digital secara daring. Dengan konsientisasi ini, baik pendidik maupun peserta didik menyadari diri sebagai subjek yang multidimensional. Ia memiliki kebebasan dan otentisitas dalam memanfaatkannya. Dalam melihatnya pula, berbagai dimensi-dimensi diri manusia seperti ekonomi, politik, religius, sosial, ekologis, kultural dicakup. Hal lain yang tentunya tidak bisa dilupakan adalah memanfaatkan teknologi digital untuk mengangkat nilai-nilai kemanusiaan secara efektif.

Ragam status dalam berbagai hal di atas, menghidupkan dan menggerakkan sebuah nilai dalam hidup bersama, yakni digital social solidarity. Digital social solidarity merupakan gerakan

${ }^{30}$ Lihat Chris Skinner. 2019. Manusia Digital-Revolusi 4.0 Melibatkan Semua Orang. Jakarta: Elex Media Komputindo, hal. 21.

${ }^{31}$ Lihat Charles Guignon. 2001. "Being as Appearing: Retrieving the Greek Experience of Phusis" dalam Richard Polt \& Gregory Fried (Ed.), A Companion to Heidegger's Introduction to Metaphysics. New Haven/London: Yale University Press, hal. 38. 
interdisipliner yang melibatkan semua subjek dalam proses pembelajaran dan dalam mengatasi situasi timpang dalam berbagai aspek di atas.

\section{KESIMPULAN}

Pandemi Covid-19 menuntut semua orang untuk berubah. Dunia pendidikan juga tidak terlepas dari tuntutan ini. Subjek yang terlibat di dalamnya harus meninggalkan modus kehidupan konvensional non-digital ke hidup digital. Manusia masuk dalam dan menjadi bagian konstitutif budaya digital. Budaya ini membentuk manusia digital satu dimensi, yang berkecenderungan mudah, murah, gratis sebagai mana disuguhkan oleh pasar kapitalisme digital. Itulah gambaran mengenai manusia yang mengenakan mentalitas baru manusia digital.

Perubahan dan peralihan dari lanskap konvensional ke lanskap digital itu bukan nir persoalan eksistensial, khususnya dalam pelaksanaan pendidikan humaniora. Persoalan-persoalan yang mendasar di balik pemanfaatan teknologi digital sebagai media pembelajaran itu adalah menghilangkan esensi pendidikan sebagai humanisasi dan hominisasi, karena di dalamnya relasi guru dan peserta didik tidak terjadi secara otentisitas, melainkan secara semu. Di dalamnya kepribadian yang dibentuk juga bukanlah pribadi yang sesungguhnya, tetapi kepribadian virtual, yang didominasi oleh rekayasa teknologi. Selain itu, pendidikan berbasis teknologi digital secara daring menyingkap persoalan keadilan, karena kesempatan yang sama dalam memperoleh pendidikan tidak terlaksana secara maksimal.

Untuk mengatasi berbagai persoalan mendasar di atas, diperlukanlah kesadaran akan keterbatasan teknologi digital itu sendiri dan kesadaran untuk menempatkan teknologi sebagai sebuah instrument atau media penghubung. Konkretnya, teknologi sebagai media berfungsi sebagai sarana, bukan sebagai subjek yang terlibat dalam humanisasi dan hominisasi. Dengan alasan ini, maka evaluasi terhadap proses pendidikan menyangkut peserta didik perlu dilakukan dengan cara abduktif, yakni memberi tempat pada berbagai kemungkinan sebagai unsur evaluasi. Di sinilah penyingkapan kebenaran itu terjadi dalam pemanfaatan teknologi digital sebagai media pembelajaran daring. Dengan demikian, penggunaan teknologi digital dalam pendidikan humaniora merupakan momen ketersingkapan kebenaran dan kebaikan etis. Para pihak yang terlibat dalam pendidikan humaniora melalui media digital mengemban tanggung jawab untuk mengembangkan sebuah gerakan solidaritas digital.

\section{REFERENSI}

Agus, Sudibyo. 2019. Jagad Digital-Pembebasan dan Penguasaan. Jakarta: KPG.

Alexander S, Rosenthal-Pubul. 2018. The Theoretic Life A Classical Ideal and its Modern Fate Reflection on The Liberal Arts. Washington DC: Springer.

Bambang, Sugiharto (ed). 2008. Humanisme dan Humaniora: Relevansinya bagi Pendidikan. Yogyakarta: Jalasutra.

Budi Hardiman, F. 2016. Heidegger dan Mistik Keseharian. Jakarta: Kepustakaan Populer Gramedia.

Chris, Skinner. 2019. Manusia Digital-Revolusi 4.0 Melibatkan Semua Orang. Jakarta: Elex Media Komputindo. 
Erich, Schmidt dan Jaren Cohen. 2014. Era Baru Digital: Cakrawalu Baru Negara, Bisnis dan Hidup Kita, Jakarta: Kompas Gramedia.

Fidler, Roger. 1997. Mediamorphosis: Undertanding New Media, Thousan Oaks, California \& New Delhi: Pine Forge Press.

Francis, Lim. 2008. Filsafat Teknologi - Don Ihde tentang Dunia, Manusia, dan Alat. Yogyakarta: Kanisius.

Heidegger, Martin. 1978. Basic Writings from Being and Time (1927) to The Task of Thinking (1964). London and Henley: Routledge \& Kegan Paul.

Heidegger, Martin. 1996. Being and Time, New York: State University of New York.

Ignas, Kleden dan Taufik Abdullah (Ed.). 2017. Paradigma Ilmu Pengetahuan dan Penelitian Ilmuilmu Sosial dan Humaniora di Indonesia. Jakarta: LIPI Press.

Joseph, Miriam, Sister. 2002. The Trivium: The Liberal Arts of Logic, Grammar, and RhetoricUnderstanding the Nature and Function of Language. Philadelphia: Paul Dry Books.

Nigel, Tubbs. 2014. Philosophy and Modern Liberal Arts Education. New York: Palgrave Macmillan.

Polt, Richard \& Gregory Fried (Ed.). 2001. A Companion to Heidegger's Introduction to Metaphysics. New Haven/London: Yale University Press.

Sastrapratedja, SJ., M. 2013. Pendidikan sebagai Humanisasi. Jakarta-Yogyakarta: Pusat Kajian Filsafat dan Pancasila-SDU Press.

Setyowibowo, SJ, A (ed). 2019. Manusia dan Budaya Indonesia, Jakarta: Penerbit Kompas.

Sudiarja, SJ, A cs (ed). 2006. Karya Lengkap Driyarkara: Esai-Esai FIlsafat Pemikiran yang Terlibat Penuh dalam Perjuangan Bangsanya. Jakarta dan Yogyakarta: Gramedia dan Kanisius.

Van Eymeren, Margawaty. 2013. Informasi Teknologis: Antropologi Teknologis Berdasarkan Pemikiran Albert Borgmann dan Walter J Ong. Jakarta: Pusat kajian Filsafat dan Pancasila. 